\title{
A Tale of Tax Policies in Open Economies
}

Stéphane Auray, Aurélien Eyquem, Paul Gomme

Décembre 2011 


\section{GATE Groupe d'Analyse et de Théorie Économique Lyon-St Étienne}

93, chemin des Mouilles 69130 Ecully - France

Tel. +33 (0)4 72866060

Fax $+33(0) 472866090$

6, rue Basse des Rives 42023 Saint-Etienne cedex 02 - France

Tel. +33 (0)4 77421960

Fax. $+33(0) 477421950$

Messagerie électronique / Email : gate@gate.cnrs.fr

Téléchargement / Download : http://www.gate.cnrs.fr - Publications / Working Papers 


\title{
A Tale of Tax Policies in Open Economies
}

\author{
Stéphane Auray* ${ }^{*} \quad$ Aurélien Eyquem ${ }^{\dagger} \quad$ Paul Gomme ${ }^{\ddagger}$
}

August 2011

\begin{abstract}
Recent financial crises in Europe as well as the periodic battles in the U.S. over the debt ceiling point to the importance of fiscal discipline among developed countries. This paper develops an open economy model, calibrated to the U.S. and a subset of the EMU, to evaluate the impact of various permanent tax changes. The first set of experiments considers a targeted one percentage point reduction in the government deficit-to-GDP ratio through raising one of: the consumption tax, the labor income tax, or the capital income tax. In terms of welfare, the consumption tax is found to be the least costly of the tax increases. A second set of experiments looks at deficitneutral tax changes: partially replacing the capital income tax with either a higher labor income tax or higher consumption tax; and partially replacing the labor income tax with an increased consumption tax. Reducing reliance on capital income taxation is welfare-enhancing, although it leads to short term losses. Reducing labor income taxation improves international competitiveness and is welfare-improving.
\end{abstract}

Keywords: Fiscal policies, open economies, public deficits, tax reforms.

JEL Classification: E31, E62, F41.

*CREST (Ensai), Université du Littoral Côte d'Opale (EQUIPPE), Université de Shebrooke (GREDI) and CIRPEE. Email: stephane.auray@ensai.fr

${ }^{\dagger}$ Université de Lyon, Lyon, F-69007, France ; Ecole Normale Supérieure de Lyon, Lyon, F-69007, France ; CNRS, GATE Lyon St Etienne, Ecully, F-69130, France ; and GREDI, Canada. Email: aurelien.eyquem@ens-lyon.fr

${ }_{\ddagger}$ Concordia University and CIREQ. Email: paul.gomme@concordia.ca 


\section{Introduction}

Recent events show that even highly developed economies can be susceptible to fiscal crises. Ireland and Greece immediately come to mind. Other countries, including Portugal, Spain and Italy, are on many watch lists. The U.K. imposed strict fiscal discipline even though there appeared to be no emergency. The recent debate in the U.S. over raising the federal government's debt limit has likewise brought to the front tax and spending issues.

This paper contributes to the study of these issues by constructing two dynamic general equilibrium, open economy models, of the U.S. and of a subset of the EMU. The focus in this paper is on tax policies; the government imposes taxes on labor income, capital income, and consumption (a value added tax, or sales tax). The first set of experiments consist of permanent tax increases aimed at reducing the government budget deficit-to-GDP ratio by one percentage point. Each of the three taxes is considered in turn. The government is assumed to behave rather naïvely in that it computes a tax increase based on the current tax base. In other words, the government ignores the general equilibrium effects of its fiscal reforms. For neither the U.S. nor the EMU do the tax reforms achieve their goal of a one percentage point reduction in the deficit-to-GDP ratio. The consumption tax is most successful in achieving the goal, followed by the labor income tax, then the capital income tax. The effects of raising the consumption tax and the labor income tax are broadly similar. In closed economy models, the effects would be virtually identical. However, in an open economy model, the consumption tax applies to both domestically-produced and imported goods, leading to some differences in the effects of these two taxes. For all three tax increases, output, consumption and hours of work fall. The real exchange rate appreciates for the consumption and labor income taxes; for the capital income tax, the real exchange rate initially depreciates, appreciating only in the longer run. The dynamics of the current account are dominated by a revaluation effect of the real exchange rate on net foreign assets, and so the movements in the current account for the U.S. differ from those of the EMU since 
the U.S. is a net creditor while the EMU is a net debtor. ${ }^{1}$ Not surprisingly, there are welfare losses associated with all tax increases. Of the three taxes, the consumption tax increase is the least costly, followed by the labor income tax. However, the temporal pattern of the welfare losses are such that increasing the capital income tax leads to measured welfare gains over relatively short horizons (a few years) and implies welfare losses in the long run.

The second set of experiments consider replacing revenue from one tax with revenue from another. These experiments are motivated by a couple of observations. First, the optimal taxation literature typically calls for lower capital income taxes (in the long run, zero). Experiments are conducted in which the capital income tax is lowered with the objective of lowering capital income tax revenue by one percent of GDP. This tax revenue is replaced by either an increase in the labor income tax or the consumption tax. As with the first set of experiments, the government takes the current tax base as given when computing the new tax system. In both cases, consumption and output rise; hours initially rise, but then fall. These tax reforms generate modest welfare gains - except for the increase in the labor income tax in the EMU - although again the temporal pattern of the welfare gains indicates that there is short term pain (welfare losses computed at short horizons) in return for long term gain. Second, it has been suggested that lowering the labor income tax rate - replacing that revenue with a higher consumption tax - may improve a country's international competitiveness, reduce the inefficiency associated with the labor income tax, and that the reduced labor income tax revenue may be paid for in part by taxing imports. This latter effect arises since the consumption tax applies to all goods, whether domestically or foreign produced. Although the effects are fairly modest, this tax reform boosts output, consumption and hours. It also leads to a depreciation of the real exchange rate. This tax reform generates modest welfare gains - around $0.1 \%$ of income for the U.S. and $0.2 \%$ for the EMU. Viewed through the lens of the model, the claims for the gains of partially replacing

\footnotetext{
${ }^{1}$ The calibration indeed implies negative net exports for the U.S. in the steady state and positive net exports for the EMU. Therefore, long run solvency implies that net foreign assets are positive for the U.S. and negative for the EMU in the steady state.
} 
the labor income tax with higher consumption tax appear to be justified.

The paper is broadly related to the body of work that studies the optimal structure of taxation. The bulk of this literature has focused on closed economy models; see Lucas and Stokey (1983) or Chari and Kehoe (1999) among many others. The open economy dimension has received decidedly less attention. Recently, Benigno and de Paoli (2010) characterized optimal fiscal policy in a small open economy model with a single income tax and public debt; they consider both steady state and business cycle fluctuations. In a richer environment with capital, sticky prices and a larger set of taxes, Auray et al. (2011) have shown that trade openness does not matter for the optimal steady state tax system when financial markets are complete, so long as one focuses on a symmetric steady state. The current paper deviates from both papers by imposing incomplete international financial markets, and an asymmetric steady state. Allowing for explicit trade relations with the rest of the world, and for potential wealth transfers (made possible by assuming incomplete international financial markets) opens up additional transmission mechanisms following tax reforms.

The paper complements the optimal taxation literature by quantifying the effects of various permanent tax reforms; the goal of the paper is not to characterize optimal fiscal policies. The full transition path for the economy following a reform is computed. One of the contributions of the paper is to consider a full set of policy instruments (here, tax rates); most open economy papers do not do so.

The paper is organized as follows. Section 2 presents the model in detail. Section 3 discusses the calibration, as well as the steady state implications of the model. Section 4 proceeds to tax policy experiments and analyzes both qualitatively and quantitatively the different policy scenarios. Section 5 concludes. 


\section{The model}

The model is composed of two regions: the domestic economy of size $n$ and the rest of the world of size $1-n$. In what follows below, rest of the world variables are denoted by an asterisk. Both areas are symmetric, except for size, their taxation system (government expenditure, tax rates and public debt), and their steady state level of total factor productivity (TFP). Regions are open to trade in final goods, and financial markets are composed of markets for local and international bonds. The market for international bonds is incomplete and does not provide perfect international risk-sharing. In each region, prices are flexible and firms operate on competitive markets. Finally, governments have access to the following instruments to finance public expenditure: taxes on final consumption, taxes on labor income, taxes on capital income, and public debt (local bonds).

\subsection{Households}

Each country is populated by an infinitely lived, representative household. The household has preferences over (contingent) streams of a composite consumption good, $c_{t}$, and hours of work, $h_{t}$, summarized by

$$
E_{0} \sum_{t=0}^{\infty} \beta^{t} u\left(c_{t}, h_{t}\right), \quad 0<\beta<1
$$

where

$$
u\left(c_{t}, h_{t}\right)=\frac{\left(c_{t}^{\kappa}\left(1-h_{t}\right)^{1-\kappa}\right)^{1-\rho}}{(1-\rho)} .
$$

Details concerning the composite consumption good are formulated later in this section. The household maximizes Eq. (1) subject to the budget constraint,

$$
\begin{aligned}
& \left(1+\tau_{c, t}\right) p_{c, t} c_{t}+p_{t}\left[k_{t}-(1-\delta) k_{t-1}+a c_{k, t}\right]+b_{t}+s_{t} f_{t}+p_{c, t} a c_{f, t} \\
& \quad=\left(1-\tau_{h, t}\right) p_{t} w_{t} h_{t}+\left(1-\tau_{k, t}\right) z_{t} p_{t} k_{t-1}+\tau_{k, t} \delta p_{t} k_{t-1}+i_{t-1} b_{t-1}+i_{t-1}^{*} s_{t} f_{t-1}+p_{t} T_{t}
\end{aligned}
$$

and the appropriate transversality condition. Starting on the right-hand side of Eq. (3), 
the first term is after-tax wage income: the tax rate on earnings is $\tau_{h, t}$, the real wage is $w_{t}$, and $p_{t}$ is the producer price, expressed in an abstract unit of account. Using this unit of account means the model can be developed along the lines of most other open economy macroeconomic models. Later, output will be selected as the numeraire good, implying $p_{t}=1$. The next term is after-tax capital income: the tax rate is $\tau_{k, t}$ and $z_{t}$ denotes the real rental rate. The term that follows is a capital consumption allowance term that reflects the tax deductibility of depreciation from capital income. The next term is the proceeds from holding domestic bonds, $b_{t-1}$, where $i_{t}$ is the nominal interest rate. The final term is income from holding foreign bonds, $f_{t}$; here, $s_{t}$ is the nominal exchange rate (defined as the price of foreign currency in terms of the domestic currency) and $i_{t-1}^{*}$ is the foreign interest rate. Finally, $T_{t}$ is a lump-sum transfer received from the government.

Now, consider the left-hand side of Eq. (3). The first term is nominal purchases of consumption goods, including payment of taxes, $\tau_{c, t} . p_{c, t}$ denotes the consumer price which is the price households pay for their consumption goods; like the producer price, the consumer price is expressed in the same unit of account. The second term is investment in (domestic) capital, $k_{t}$, net of adjustment costs, $a c_{k, t}$, specified as in Mendoza (1991a):

$$
a c_{k, t}=\frac{\phi_{k}}{2}\left(k_{t}-k_{t-1}\right)^{2}
$$

The remaining terms are purchases of domestic bonds, $b_{t}$, and foreign bonds, $f_{t}$, net of intermediation costs on foreign debt, $a c_{f, t}:^{2}$

$$
a c_{f, t}=\frac{\phi_{f}}{2}\left(\frac{s_{t} f_{t}}{p_{c, t}}-\frac{s f}{p_{c}}\right)^{2},
$$

where variables without time subscripts denote steady state values.

The representative household chooses $c_{t}, h_{t}, k_{t}, b_{t}$ and $f_{t}$ to maximize expected lifetime

\footnotetext{
${ }^{2}$ Since international bonds are denominated in the foreign currency, it is assumed that foreign households need not pay the intermediation cost, in the same way that domestic households do not pay intermediation costs on domestic bonds.
} 
utility Eq. (1) subject to the budget constraint Eq. (3). The first order conditions are:

$$
\begin{aligned}
u_{c}\left(c_{t}, h_{t}\right)-\left(1+\tau_{c, t}\right) p_{c, t} \lambda_{t} & =0, \\
-u_{h}\left(c_{t}, h_{t}\right)-\left(1-\tau_{h, t}\right) p_{t} w_{t} \lambda_{t} & =0, \\
p_{t} \lambda_{t} q_{t}-\beta E_{t}\left[p_{t+1} \lambda_{t+1}\left(q_{t+1}+\left(1-\tau_{k, t+1}\right)\left(z_{t+1}-\delta\right)\right)\right] & =0, \\
\lambda_{t}-i_{t} \beta E_{t}\left[\lambda_{t+1}\right] & =0, \\
s_{t} \lambda_{t}\left(1+\phi_{f}\left(\frac{s_{t} f_{t}}{p_{c, t}}-\frac{s f}{p_{c}}\right)\right)-i_{t}^{*} \beta E_{t}\left[s_{t+1} \lambda_{t+1}\right] & =0,
\end{aligned}
$$

where $q_{t}=1+\phi_{k}\left(k_{t}-k_{t-1}\right)$ is Tobin's $\mathrm{Q}$ and $\lambda_{t}$ is the Lagrange multiplier associated with the budget constraint. Eliminate the Lagrange multiplier and rewrite the above equations in real terms:

$$
\begin{gathered}
\frac{u_{h}\left(c_{t}, h_{t}\right)}{u_{c}\left(c_{t}, h_{t}\right)}+\frac{\left(1-\tau_{h, t}\right) p_{t}}{\left(1+\tau_{c, t}\right) p_{c, t}} w_{t}=0, \\
\frac{u_{c}\left(c_{t}, h_{t}\right)}{\left(1+\tau_{c, t}\right)}=\beta E_{t}\left\{\frac{r_{t+1} u_{c}\left(c_{t+1}, h_{t+1}\right)}{\left(1+\tau_{c, t+1}\right)}\right\}, \\
\frac{q_{t} u_{c}\left(c_{t}, h_{t}\right)}{\left(1+\tau_{c, t}\right)}=\beta E_{t}\left\{\frac{\pi_{t+1} u_{c}\left(c_{t+1}, h_{t+1}\right)}{\pi_{c, t+1}\left(1+\tau_{c, t}\right)}\left(q_{t+1}+\left(1-\tau_{k, t+1}\right)\left(z_{t+1}-\delta\right)\right)\right\}, \\
{\left[1+\phi_{f}\left(f_{t}^{r}-f^{r}\right)\right] \frac{s_{t}^{r} u_{c}\left(c_{t}, h_{t}\right)}{1+\tau_{c, t}}=\beta E_{t}\left\{\frac{s_{t+1}^{r} u_{c}\left(c_{t+1}, h_{t+1}\right) r_{t+1}^{*}}{1+\tau_{c, t+1}}\right\},}
\end{gathered}
$$

where $r_{t+1}=i_{t} / \pi_{c, t+1}$ is the real interest rate, $\pi_{c, t}=p_{c, t} / p_{c, t-1}$ is the gross rate of change in consumer prices, $\pi_{t}=p_{t} / p_{t-1}$ is the gross rate of change in producer prices, $s_{t}^{r}=s_{t} p_{c, t}^{*} / p_{c, t}$ the real exchange rate, and $f_{t}^{r}=s_{t} f_{t} / p_{c, t}$ is the real net foreign assets of the household. Since the consumer and producer prices are expressed in units of account, the terms $\pi_{c, t}$ and $\pi_{t}$ do not correspond to traditional measures of inflation. Eq. (11) is the standard labor supply function, describing the intratemporal trade-off between consumption and time spent working. Eq. (12) is the intertemporal Euler equation governing purchases of domestic bonds. As such, it relates the marginal rate of substitution between consumption at dates $t$ and $t+1$ to the real interest rate. Eq. (13) governs the accumulation of domestic capital. Finally, Eq. (14) determines the accumulation of foreign bonds. It relates the marginal rate of 
substitution for consumption between two dates (accounting for changes in the consumption tax, and the intermediation cost on acquiring foreign bonds) to changes in the real exchange rate and the real interest rate on foreign bonds.

Whereas investment goods are composed exclusively of domestic output, consumption goods are composed of domestic and foreign goods. As in Benigno and de Paoli (2010), aggregate consumption is a composite of consumption of a good produced at home $(h)$, and a good produced in the rest of the world $(f)$ according to:

$$
c_{t}=\left(\varphi^{\frac{1}{\mu}} c_{h, t}^{\frac{\mu-1}{\mu}}+(1-\varphi)^{\frac{1}{\mu}} c_{f, t}^{\frac{\mu-1}{\mu}}\right)^{\frac{\mu}{\mu-1}},
$$

where $\varphi=1-(1-n) \alpha$ governs the importance of home goods in the composite; it depends on $n$, the relative size of the domestic economy, and $\alpha$, which measures trade openness. Symmetrically, the consumption of a representative household in the rest of the world is:

$$
c_{t}^{*}=\left(\varphi^{* \frac{1}{\mu}} c_{h, t}^{* \frac{\mu-1}{\mu}}+\left(1-\varphi^{*}\right)^{\frac{1}{\mu}} c_{f, t}^{* \frac{\mu-1}{\mu}}\right)^{\frac{\mu}{\mu-1}}
$$

where $\varphi^{*}=n \alpha$. Assuming that the law of one price holds at the producer level, consumer prices are given by

$$
\begin{gathered}
p_{c, t}=\left(\varphi\left(p_{t}\right)^{1-\mu}+(1-\varphi)\left(s_{t} p_{t}^{*}\right)^{1-\mu}\right)^{\frac{1}{1-\mu}}, \\
p_{c, t}^{*}=\left(\left(1-\varphi^{*}\right)\left(p_{t}^{*}\right)^{1-\mu}+\varphi^{*}\left(s_{t}^{-1} p_{t}\right)^{1-\mu}\right)^{\frac{1}{1-\mu}} .
\end{gathered}
$$

In these expressions, $\mu \geq 1$ is the elasticity of substitution between domestic and foreign goods.

Optimal demands for domestic and foreign produced goods can be obtained from a cost minimization problem,

$$
\min _{\left\{c_{h, t}, c_{f, t}\right\}} p_{t} c_{h, t}+s_{t} p_{t}^{*} c_{f, t}
$$

subject to Eq. (15), with a similar problem for the foreign consumer. Defining terms of trade as $x_{t}=s_{t} p_{t}^{*} / p_{t}$ and making use of the structure of price indices, optimal demands of 
domestic and foreign production goods are:

$$
\begin{gathered}
c_{h, t}=\varphi\left(\varphi+(1-\varphi) x_{t}^{1-\mu}\right)^{\frac{\mu}{1-\mu}} c_{t}, \\
c_{h, t}^{*}=\varphi^{*}\left(\left(1-\varphi^{*}\right) x_{t}^{1-\mu}+\varphi^{*}\right)^{\frac{\mu}{1-\mu}} c_{t}^{*}, \\
c_{f, t}^{*}=\left(1-\varphi^{*}\right)\left(\left(1-\varphi^{*}\right)+\varphi^{*} x_{t}^{\mu-1}\right)^{\frac{\mu}{1-\mu}} c_{t}^{*}, \\
c_{f, t}=(1-\varphi)\left(\varphi x_{t}^{\mu-1}+(1-\varphi)\right)^{\frac{\mu}{1-\mu}} c_{t} .
\end{gathered}
$$

\section{$2.2 \quad$ Firms}

The domestic economy has a measure $n$ of competitive firms. The representative firm produces output, $y_{t}$, using domestic labor, $\tilde{h}_{t}$, and physical capital, $\tilde{k}_{t-1}$ according to the following production function: ${ }^{3}$

$$
y_{t}=a_{t} \tilde{k}_{t-1}^{\phi} \tilde{h}_{t}^{1-\phi}
$$

where $a_{t}$ is total factor productivity. Profit maximization implies that factors will be optimally allocated according to

$$
(1-\phi) z_{t} \tilde{k}_{t-1}=\phi w_{t} \tilde{h}_{t}
$$

Further, optimal pricing under perfect competition implies that the producer price index equates the nominal marginal cost; hence:

$$
w_{t}^{1-\phi} z_{t}^{\phi}=\phi^{\phi}(1-\phi)^{1-\phi} a_{t} .
$$

\subsection{Governments}

Each government finances an exogenous stream of public expenditures by levying distortionary taxes on factor incomes (labor and capital), and on consumption. Each government may also issue non-state contingent local bonds to finance potential deficits. The budget

\footnotetext{
${ }^{3}$ In the foreign economy, a measure $1-n$ of firms produce according to a similar technology, with the same market structure.
} 
constraint of the domestic government is:

$$
d_{t}-i_{t-1} d_{t-1}=p_{t} g_{t}+p_{t} \bar{T}_{t}-p_{c, t} \tau_{c, t} \bar{c}_{t}-p_{t} \tau_{h, t} w_{t} \bar{h}_{t}-p_{t} \tau_{k, t}\left(z_{t}-\delta\right) \bar{k}_{t-1}
$$

where $\bar{c}_{t}, \bar{h}_{t}, \bar{k}_{t-1}$ and $\bar{T}_{t}$ are per capita quantities. ${ }^{4}$

\subsection{Equilibrium}

To start, select output as the numeraire good in each country. Consequently, the producer prices are $p_{t}=p_{t}^{*}=1$. All date $t$ prices, including factor prices, are now expressed in terms of output. As a consequence, $\pi_{t}=p_{t} / p_{t-1}=1$, and the terms of trade are equal to the exchange rate: $x_{t}=s_{t}$.

Definition 1 A competitive equilibrium consists of an allocation,

$$
\left\{\tilde{y}_{t}, \tilde{y}_{t}^{*}, h_{t}, \tilde{h}_{t}, \bar{h}_{t}, h_{t}^{*}, \tilde{h}_{t}^{*}, \bar{h}_{t}^{*}, c_{t}, \bar{c}_{t}, c_{t}^{*}, \bar{c}_{t}^{*}, k_{t}, \tilde{k}_{t}, \bar{k}_{t}, k_{t}^{*}, \tilde{k}_{t}^{*}, \bar{k}_{t}^{*}, b_{t}, b_{t}, b_{t}^{*}, f_{t}, f_{t}^{*}\right\}_{t=0}^{\infty},
$$

a sequence of prices,

$$
\left\{p_{c, t}, p_{c, t}^{*}, w_{t}, w_{t}^{*}, z_{t}, z_{t}^{*}, r_{t}, r_{t}^{*}, s_{t}, s_{t}^{r}\right\}_{t=0}^{\infty}
$$

a sequence for exogenous government spending and transfers,

$$
\left\{g_{t}, g_{t}^{*}, T_{t}, T_{t}^{*}, \bar{T}_{t}, \bar{T}_{t}^{*}\right\}_{t=0}^{\infty}
$$

and a sequence of fiscal policies,

$$
\left\{\tau_{c, t}, \tau_{h, t}, \tau_{k, t}, \tau_{c, t}^{*}, \tau_{h, t}^{*}, \tau_{k, t}^{*}, d_{t}, d_{t}^{*},\right\}_{t=0}^{\infty}
$$

such that:

1. The allocation for the household solves its problem given prices and fiscal policy.

2. The allocation for the firm solves its problem given prices.

\footnotetext{
${ }^{4} \mathrm{~A}$ similar budget constraint holds for the foreign government.
} 
3. Governments satisfy their budget constraints.

4. Markets clear:

- Final goods markets:

$$
\begin{aligned}
y_{t}= & \varphi\left(\varphi+(1-\varphi) s_{t}^{1-\mu}\right)^{\frac{\mu}{1-\mu}}\left(c_{t}+a c_{f, t}\right) \\
& +\frac{\varphi^{*}(1-n)}{n}\left(\left(1-\varphi^{*}\right) s_{t}^{1-\mu}+\varphi^{*}\right)^{\frac{\mu}{1-\mu}} c_{t}^{*} \\
& +k_{t}-(1-\delta) k_{t-1}+g_{t}+a c_{k, t}, \\
y_{t}^{*}= & \left(1-\varphi^{*}\right)\left(\left(1-\varphi^{*}\right)+\varphi^{*} s_{t}^{\mu-1}\right)^{\frac{\mu}{1-\mu}} c_{t}^{*} \\
& +\frac{(1-\varphi) n}{1-n}\left(\varphi s_{t}^{\mu-1}+(1-\varphi)\right)^{\frac{\mu}{1-\mu}}\left(c_{t}+a c_{f, t}\right) \\
& +k_{t}^{*}-(1-\delta) k_{t-1}^{*}+g_{t}^{*}+a c_{k, t}^{*} .
\end{aligned}
$$

- Labor markets:

$$
h_{t}=\tilde{h}_{t}, \text { and } h_{t}^{*}=\tilde{h}_{t}^{*} .
$$

- Capital goods markets:

$$
k_{t-1}=\tilde{k}_{t-1} \text {, and } k_{t-1}^{*}=\tilde{k}_{t-1}^{*} \text {. }
$$

- Local bonds markets:

$$
n b_{t}=d_{t}, \text { and }(1-n) b_{t}^{*}=d_{t}^{*} \text {. }
$$

- International bonds markets:

$$
n f_{t}+(1-n) f_{t}^{*}=0
$$

5. Finally, the aggregation of budget constraints and market clearing conditions yields the dynamics of (real) domestic net foreign assets:

$$
\begin{aligned}
f_{t}^{r}-r_{t-1}^{*} \frac{s_{t}^{r}}{s_{t-1}^{r}} f_{t-1}^{r} & =\frac{1}{p_{c, t}} \frac{\varphi^{*}(1-n)}{n}\left(\left(1-\varphi^{*}\right) s_{t}^{1-\mu}+\varphi^{*}\right)^{\frac{\mu}{1-\mu}} c_{t}^{*} \\
& -\left(1-\frac{1}{p_{c, t}} \varphi\left(\varphi+(1-\varphi) s_{t}^{1-\mu}\right)^{\frac{\mu}{1-\mu}}\right)\left(c_{t}+a c_{f, t}\right) .
\end{aligned}
$$


In addition, the structure of price indices and the assumption of flexible prices imply that the real exchange rate and terms of trade are related according to:

$$
s_{t}^{r}=\left(\frac{\left(1-\varphi^{*}\right) s_{t}^{1-\mu}+\varphi^{*}}{\varphi+(1-\varphi) s_{t}^{1-\mu}}\right)^{\frac{1}{1-\mu}} .
$$

A summary of equilibrium conditions expressed in real terms can be found in Appendix A.

\section{Steady state and calibration}

\subsection{Steady state}

An issue that arises in open economy models with incomplete financial markets is the steady state indeterminacy of the real exchange rate, $s_{t}^{r}$, and the terms of trade, $x_{t}$. In models with complete international asset markets, the real exchange rate depends on the ratio of marginal utilities for the domestic and foreign households. With incomplete markets, the model is closed with an equation for net foreign assets, namely the steady state version of Eq. (34). In the literature, there are two approaches to the steady state indeterminacy problem: calibrate the value of net foreign assets as in Benigno (2009), or normalize the steady state value of the terms of trade, $x_{t}$, and so the exchange rates, $s_{t}$ and $s_{t}^{r}$. In the interests of tractability, the latter approach is employed; steady state $s$ is normalized to equal one.

\subsection{Calibration}

The analysis alternatively focuses on the US and the EMU within a large group of OECD countries. ${ }^{5}$ Thus, when we consider the U.S. (respectively the EMU), the rest of the world is composed of the remaining OECD countries of the group. As stated earlier, the model is symmetric except for the fiscal system, for the size, for TFP and for time allocated to work.

\footnotetext{
${ }^{5}$ The EMU consists of its core members: Austria, Belgium, Finland, France, Germany, Greece, Ireland, Italy, Luxembourg, Netherlands, Portugal, and Spain. The OECD sample includes: Australia, Austria, Belgium, Canada, Czech Republic, Denmark, Finland, France, Germany, Greece, Hungary, Ireland, Italy, Japan, Korea, Luxembourg, Mexico, Netherlands, New Zealand, Norway, Poland, Portugal, Slovak Republic, Spain, Sweden, Switzerland, United Kingdom, and United States. See Appendix C for a complete description of the data.
} 
Common parameters. The model is quarterly and the subjective discount factor $\beta$ is equal to 0.99 , consistent with a $4 \%$ annual real interest rate, a common value in the macroeconomic literature. The risk-aversion parameter is set to $\rho=2$; Backus et al. (1992) use the same value. The share of capital income in the GDP is commonly set to $\phi=0.3$, and the depreciation rate, $\delta$, is assumed to be $7 \%$ annually; both of these values are based on data from the U.S. as reported in Gomme and Rupert (2007). As in Mendoza (1991b), capital adjustment costs are set to $\phi_{k}=0.025$. The degree of trade openness is $\alpha=0.3$ which corresponds to the share of total imports in GDP for the OECD countries in 2008. Finally, intermediation parameter for foreign assets is set to $\phi_{f}=0.001$, following Benigno (2009) and Schmitt-Grohé and Uribe (2003), and the elasticity of substitution between domestic and foreign goods is set to $\mu=1.5$, as in Backus et al. (1993).

Specific parameters. The size $n$ is set to the share of total population in the OECD countries included in the sample. For the U.S., $n=0.37$ while for the EMU, $n=0.29$. Total factor productivity is calculated using the output per worker. When dealing with groups of countries, TFP is computed as a weighted average of individual country TFPs where the weights are given by the output shares of the countries. Domestic TFP is normalized to one $(a=1)$, which is innocuous since what matters is relative TFP. For the U.S., foreign TFP is $a^{*}=0.7$ while for the EMU, $a^{*}=1.09$. The preference parameter $\kappa$ governs the importance of consumption-versus-leisure in utility. For the U.S., $\kappa$ is chosen such that in steady state, hours worked are $30 \%$ of the time endowment; for the EMU, 27\%, which matches the average total annual hours worked over total time awake. ${ }^{6}$ Table 1 summarizes the benchmark calibration of the models.

\subsection{Benchmark steady state and the Laffer curves}

The implied benchmark steady state is summarized in Table 2. Perhaps the most salient feature of the steady states is that both the U.S. and EMU are predicted to have modest

\footnotetext{
${ }^{6}$ Source: Authors' calculations based on OECD data.
} 
Table 1: Parameter values in the benchmark calibration

Size, $n$

\begin{tabular}{cccc} 
U.S. $^{a}$ & & EMU $^{b}$ \\
\cline { 1 - 1 } $37 \%$ & & $29 \%$ \\
$70 \%$ & & $109 \%$ \\
$28.97 \%$ & & $30.64 \%$ \\
$30.69 \%$ & & $29.72 \%$ \\
$30.12 \%$ & & $46.94 \%$ \\
$36.93 \%$ & & $29.76 \%$ \\
$6.5 \%$ & & $19.15 \%$ \\
$16.92 \%$ & & $8.99 \%$ \\
$49.77 \%$ & & $45.45 \%$ \\
$44.39 \%$ & $46.70 \%$ \\
0.3705 & 0.3687 \\
0.99 & \\
2 & 0.3 \\
0.0175 \\
0.025 \\
0.001 \\
0.3 \\
1.5
\end{tabular}

Relative TFP, $a^{*} / a$

Share of public exp. in GDP, $\gamma_{g}=g / y$

Share of public exp. in GDP, $\gamma_{g}^{*}=g^{*} / y^{*}$

Labor income tax rate, $\tau_{h}$

Labor income tax rate, $\tau_{h}^{*}$

Consumption tax rate, $\tau_{c}$

Consumption tax rate, $\tau_{c}^{*}$

Capital income tax rate, $\tau_{k}$

Capital income tax rate, $\tau_{k}^{*}$

Weight on consumption in preferences, $\kappa$

Discount factor, $\beta$

Risk-aversion, $\rho$

Share of capital income in GDP, $\phi$

Depreciation rate, $\delta$

0.0175

Capital adjustment costs, $\phi_{k}$

0.025

Foreign assets adjustment costs, $\phi_{f}$

0.3

Goods elasticity of substitution, $\mu$

1.5

Source: OECD databases. $a$ vs. (OECD less U.S.), $b$ : vs. (OECD less EMU). 
Table 2: Benchmark steady state values

\begin{tabular}{|c|c|c|}
\hline & \multicolumn{2}{|c|}{ U.S. vs OECD less U.S. } \\
\hline & Home economy & Foreign economy \\
\hline Output, $y$ & 0.7306 & 0.4665 \\
\hline Consumption, $c$ & 0.4608 & 0.2289 \\
\hline Hours worked, $h$ & 0.3000 & 0.3117 \\
\hline Capital stock, $k$ & 5.8275 & 3.9241 \\
\hline $100 \times$ Capital rental, $z$ & 3.7610 & 3.5664 \\
\hline Real wage, $w$ & 1.7045 & 1.0476 \\
\hline \multirow[t]{3}{*}{ Public deficit (in $\%$ of annual $y$ ) } & 2.7108 & 2.0483 \\
\hline & \multicolumn{2}{|c|}{ EMU vs OECD less EMU } \\
\hline & Home economy & Foreign economy \\
\hline Output, $y$ & 0.6698 & 0.8759 \\
\hline Consumption, $c$ & 0.3297 & 0.5046 \\
\hline Hours worked, $h$ & 0.2700 & 0.3138 \\
\hline Capital stock, $k$ & 5.5789 & 7.2085 \\
\hline $100 \times$ Capital rental, $z$ & 3.6017 & 3.6451 \\
\hline Real wage, $w$ & 1.7364 & 1.9538 \\
\hline Public deficit (in \% of annual $y$ ) & 1.2191 & 2.8136 \\
\hline
\end{tabular}

deficits; $2.7 \%$ for the U.S. and $1.2 \%$ for the EMU. Since these calculations are for steady states, these deficits can properly be thought of as structural deficits. For 2009, both the U.S. and EMU experienced larger deficits than implied by the model's steady states; $11.2 \%$ for the U.S. and $6.3 \%$ for the EMU. A natural interpretation of these facts is that the bulk of the deficits in 2009 were not structural, and can be attributed to the recessions experienced by both the U.S. and EMU. Nonetheless, that both the U.S. and EMU have structural deficits points to the importance of deficit reduction programs like those analyzed below.

By way of preliminary analysis, Figure 1 presents so-called Laffer curves for the steady states of the models. ${ }^{7}$ This figure will prove helpful in understanding some of the experiments conducted below. The consumption tax rates for both the U.S. and EMU are well below their revenue-maximizing values. The labor income tax rates are also below their revenuemaximizing levels, although the EMU is closer to the maximum than is the U.S. Finally, the

\footnotetext{
${ }^{7}$ In computing steady states, the real exchange rate is held fixed at one; see the discussion on indeterminacy of steady state in Section 3.1.
} 
Figure 1: Laffer curves

(a) Tax on labor income, $\tau_{h}$

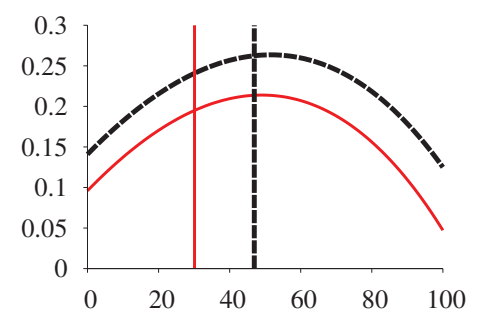

(b) Consumption tax, $\tau_{c}$

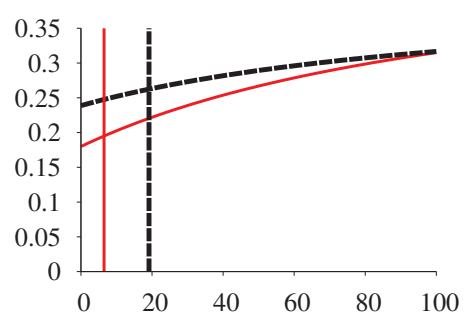

(c) Tax on capital income, $\tau_{k}$

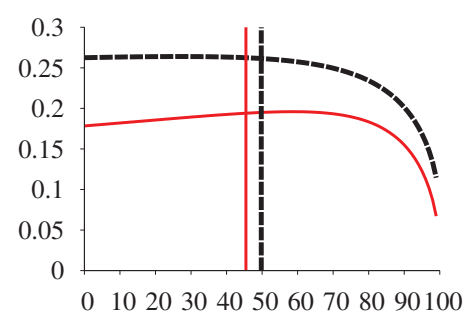

Legend: Red solid line: U.S.; black dashed line: EMU. Vertical lines indicate current tax rates.

U.S. capital income tax rate is below its revenue-maximizing value while the EMU is above; in both cases, though, the revenue function is quite flat around current tax rates.

\section{Policy experiments}

This section considers several policy experiments. The first set are permanent tax increases that are targeted to reduce the government deficit-to-GDP ratio by one percentage point. The next set reduces the capital income tax rate, designed to reduce capital income tax revenue by one percent of GDP, replacing those revenues with either an increased consumption or labor income tax. The final experiment looks at shifting the burden of taxes from labor income to the consumption tax.

\subsection{Deficit reduction: permanent tax increases}

The first set of experiments consider permanent tax increases aimed at reducing government budget deficits. The economy is initially in steady state. The government then raises one tax with the goal of reducing the deficit-to-GDP ratio by one percentage point. In setting taxes, the government acts naïvely in the sense that it does not take into account the general equilibrium effects of the tax change. Instead, the government takes as given its current tax base, then computes the required tax rate increase to achieve its goal of a one percentage 
point reduction in the deficit-to-GDP ratio.

To be absolutely clear about the nature of the experiment, consider raising labor income taxes in the U.S. The government's goal is to reduce the deficit-to-GDP ratio from $2.7 \%$ to $1.7 \%$. Given that steady state output is 0.7306 , the required reduction in the deficit is 0.0073. Hours worked are 0.3 while the real wage is 1.7045 , so labor income is 0.5114 . The government computes the required increase in labor income taxes as the required deficit reduction divided by labor income, or 1.4288 percentage points.

The results of these deficit reduction experiments are summarized in Figures 2 and 3. Starting with the U.S., the increase in the labor income tax, $\tau_{h}$, is 1.4 percentage points; for the consumption tax, 1.6 percentage points; and for the capital income tax, 6.2 percentage points. None of these policies has the desired one percentage point decline in the deficitto-GDP ratio which points to the importance of considering general equilibrium effects, a consideration first pointed out by Lucas, Jr. (1976). The consumption tax lowers this ratio by roughly 0.2 percentage points (both impact and long run); the labor income tax by 0.14 percentage points; and the capital income tax by 0.15 percentage points on impact, and 0.11 percentage points in the long run.

The macroeconomic effects of the increase in the consumption and labor income taxes are broadly similar, although the effects of the consumption tax increase are smaller than that of the labor income tax. Both lead to modest declines in output, consumption, hours worked and the capital stock, with the impact effect close to the long run effect. These negative effects of raising taxes are precisely what one would expect to see. The increase in the labor income tax lowers the after-tax real wage, and so reduces hours of work. From Eq. (11), the intratemporal Euler equation governing the labor-leisure choice of households, one can see that the effect of increasing the consumption tax have similar effects to increasing the labor income tax. In a closed economy model, the effects of the labor income tax and consumption tax would be more similar. The difference is that in an open economy model, consumption is composed of both domestic and foreign goods, so the consumption tax applies to both 
Figure 2: U.S.: Permanent tax increase targeted to reduce the deficit-to-GDP ratio by 1 percentage point.

(a) Output

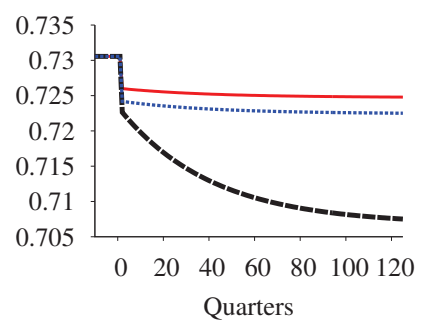

(d) Capital Stock

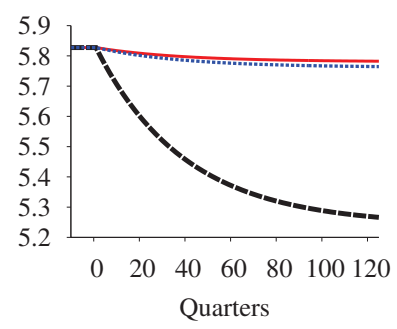

(g) Real Exch. Rate

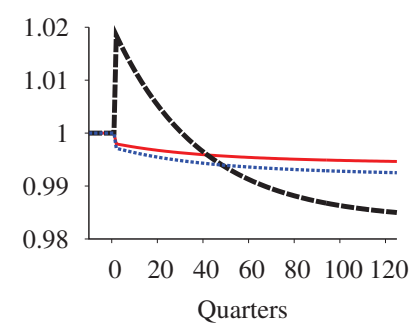

(b) Consumption

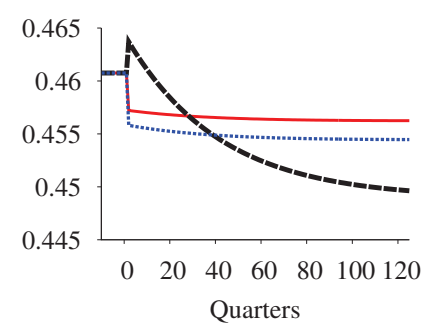

(e) Real Int. Rate

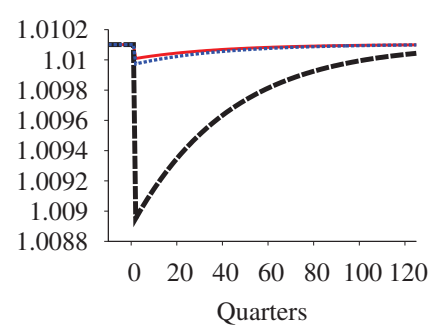

(h) Net Exports

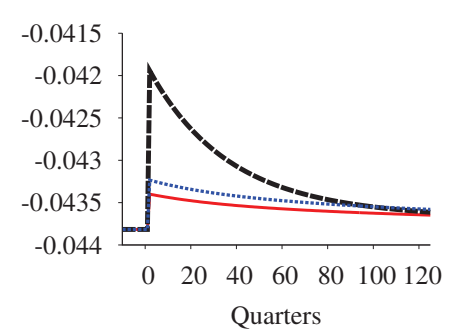

(c) Hours

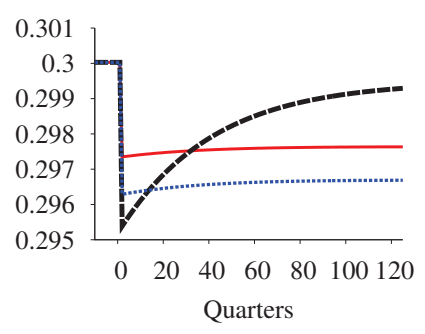

(f) Deficit (\% of GDP)

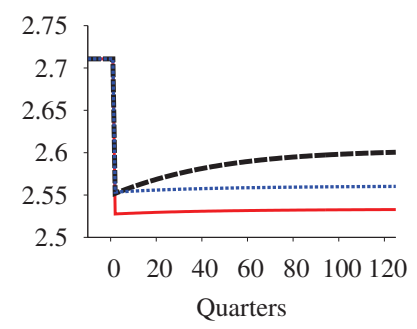

(i) $\mathrm{CA}(\%$ of GDP)

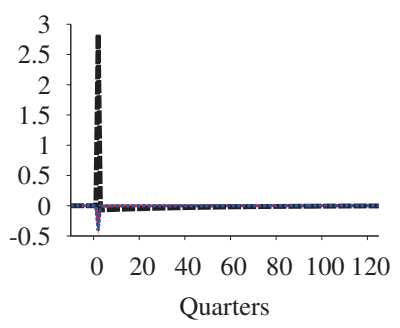

Legend: Solid red line, increase in $\tau_{c}$; dotted blue line, increase in $\tau_{h}$; dashed black line, increase in $\tau_{k}$. The increase in labor income tax is 1.4 percentage points; for the consumption tax, 1.6 percentage points; and for the capital income tax, 6.2 percentage points. 
Figure 3: EMU: Permanent tax increase targeted to reduce the deficit-to-GDP ratio by 1 percentage point.

(a) Output

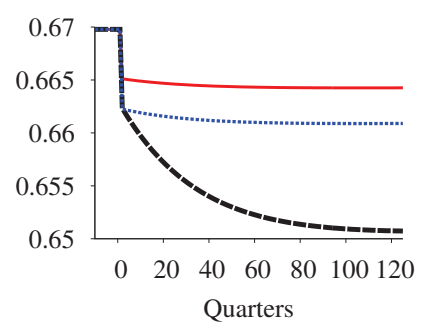

(d) Capital Stock

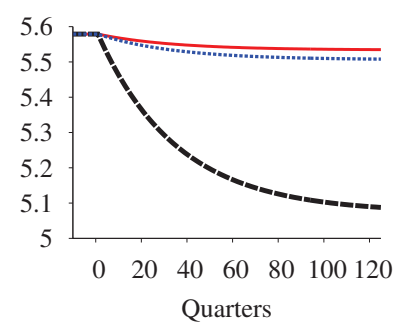

(g) Real Exchange Rate

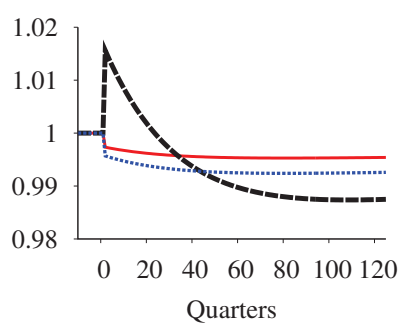

(b) Consumption

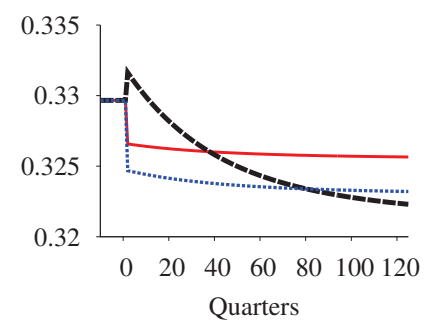

(e) Real Interest Rate

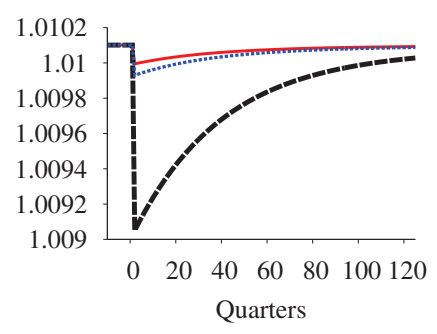

(h) Net Exports

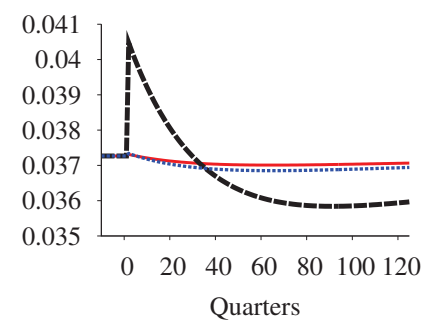

(c) Hours

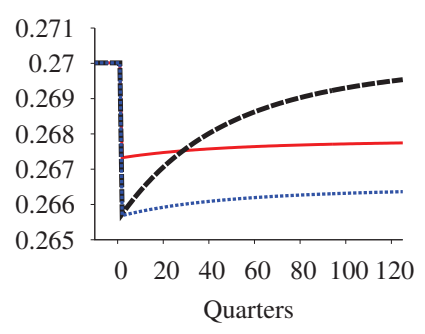

(f) Deficit (\% of GDP)

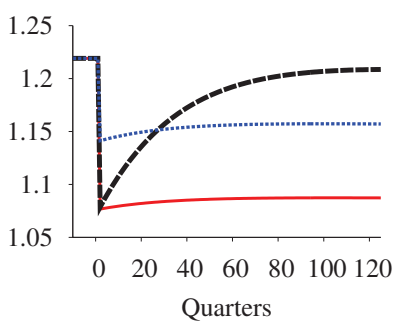

(i) $\mathrm{CA}(\%$ of GDP)

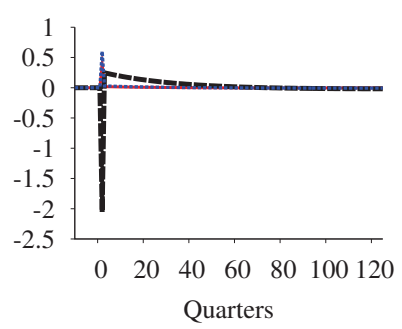

Legend: Solid red line, increase in $\tau_{c}$; dotted blue line, increase in $\tau_{h}$; dashed black line, increase in $\tau_{k}$. The increase in labor income tax is 1.4 percentage points; for the consumption tax, 2 percentage points; and for the capital income tax, 6.5 percentage points. 
domestic and foreign goods (consumed in the home country). Both tax increases lead to very modest appreciations in the real exchange rate; the long run effects are somewhat larger. Net exports rise slightly. The mechanics behind the results for net exports and real exchange rate are as follows. A real exchange rate appreciation discourages foreign consumption of domestic goods (exports fall) and encourages domestic consumption of foreign goods (imports rise). The real exchange rate appreciation would, by itself, lead to a fall in net exports. However, the sum of domestic consumption and investment falls by more than domestic output; this effect dominates and so net exports rise.

The dynamics of the current account (CA) are markedly different from those of net exports, at least on impact when the current account moves very strongly down. Using the fact that

\section{Current Account + Capital Account $=0$,}

one can examine the behavior of the capital account; it is a bit easier to deal with. The capital account is given by the change in net foreign assets, $f_{t}^{r}$. Examining Eq. (34) which describes the evolution of net foreign assets, the right-hand side of this equation is almost net exports - there is an additional term related to intermediation costs in purchasing foreign assets. The movement in the real exchange rate leads to a revaluation of net foreign assets that results in a sharp movement in the capital and current accounts. In other words, the impact effect on the current account is predominantly due to this revaluation effect, not the change in net exports. That the current account subsequently returns to essentially zero is in accord with intertemporal current account theory.

The macroeconomic effects of an increase in the capital income tax are quite different from those of the other taxes. In this case, consumption rises on impact, followed by a long transition to its new long run value. Hours fall sharply on impact, but then almost recover to their previous steady state value. In the long run, the capital stock falls by $10 \%$. In this case, the principal effect of the tax rate increase operates through Eq. (12) which governs 
capital accumulation. In steady state, this equation reads

$$
1=\beta\left[1+\left(1-\tau_{k}\right)(z-\delta)\right]
$$

Consequently, the increase in the capital income tax rate manifests itself in an increase in $z$, the rental rate for capital. Since hours worked are little affected by this experiment, the increase in $z$ must come about through a decline in the capital stock. On impact, the increase in the capital income tax rate leads to a rise in domestic consumption as households draw down their capital holdings. While domestic consumption rises, investment falls; on net, the fall in domestic consumption and investment exceeds that of output. In this case, a real exchange rate depreciation lowers imports and raises exports. Consequently, net exports rise. Again, the impact effect on the current account is dominated by the revaluation effect on net foreign assets. Since the U.S. is a net creditor, the real exchange rate depreciation translates into an upward spike in the current account.

Following the increase in the capital income tax, momentary utility rises while it falls for the other two taxes. However, in the longer term, the deleterious effects of the capital income tax drives momentary utility below that seen under the labor income and consumption tax increases. Of course, the true measure of the welfare effects of such policy changes should be measured by their effects on lifetime utility, and all three tax increase policies will necessarily reduce lifetime utility. However, it is possible that policymakers operate on a shorter horizon and may view as quite desirable the apparent increases in utility under the capital income tax increase.

For the EMU, the government again targets a one percentage point reduction in the deficit-to-GDP ratio, again omitting the general equilibrium effects. In this case, the increase in the consumption tax is 2 percentage points; for the labor income tax, 1.4 percentage points; and for the capital income tax, 6.5 percentage points. All of these increases are of a similar magnitude to the U.S. case already discussed. Qualitatively, the results are quite similar to the U.S. case. As with the U.S., the consumption tax ends up having the largest impact 
on the deficit-to-GDP ratio in the long run (roughly 0.13 percentage points). The labor income tax reduces this ratio by 0.06 percentage points in the long run, or about half of the effect of the consumption tax. While the capital income tax has a sizable effect on the deficit-to-GDP ratio on impact (0.14 percentage points, the same as the consumption tax), its long run impact is negligible (less than 0.02 percentage points).

A final issue concerns the welfare losses associated with the various tax increases. The goal is to find a (constant) Hicksian equivalent variation payment, $\xi$, such that

$$
\sum_{t=0}^{J} \beta^{t} u\left(c_{t}+\xi, h_{t}\right)=u\left(c^{s s}, h^{s s}\right) \sum_{t=0}^{J} \beta^{t},
$$

where the date of the tax reform is normalized to $t=0, J$ is the horizon over which the welfare loss is to be computed, and the "ss" superscripts denote steady state values. The payment $\xi$ is the increment to consumption necessary to make households indifferent between the pre- and post-reform streams of consumption and hours worked. This payment is expressed as a fraction of steady state output and so is "unit free." While the "correct" measure of the welfare loss is calculated for $J=\infty$, computing the welfare loss for shorter horizons gives some sense of the temporal timing of the welfare losses. The shorter horizons may also partially capture the political dimension of the deficit reduction problem.

Table 3 presents the welfare losses (gains if negative) of the three tax increases for both the U.S. and EMU. At the longest horizons (that is, correctly accounting for the change in households' lifetime utility), the consumption tax is the least costly tax increase at roughly $0.2 \%$ of output for the U.S. and $0.3 \%$ for the EMU. Again, the reason why the consumption tax is less costly than the labor income tax is because in an open economy model, the consumption tax applies to both domestic- and foreign-produced goods. The costs for both the labor income and consumption tax increase are monotonically increasing in the horizon, showing that the costs of reform along the transition path are smaller than if the economy were to jump from one steady state to another. Indeed, the last line in Table 3 computes the welfare loss across steady states. While the differences between steady state welfare loss 
Table 3: Deficit reductions: Welfare losses as a percentage of steady state output

\begin{tabular}{|c|c|c|c|c|c|c|}
\hline \multirow[b]{2}{*}{ Horizon } & \multicolumn{3}{|c|}{ U.S. } & \multicolumn{3}{|c|}{ EMU } \\
\hline & $\tau_{h}$ & $\tau_{c}$ & $\tau_{k}$ & $\tau_{h}$ & $\tau_{c}$ & $\tau_{k}$ \\
\hline 1 & 0.108600 & 0.076666 & -1.107808 & 0.247934 & 0.152589 & -0.784628 \\
\hline 4 & 0.118878 & 0.084048 & -1.014952 & 0.258633 & 0.159266 & -0.718781 \\
\hline 16 & 0.154075 & 0.109326 & -0.691719 & 0.295518 & 0.182279 & -0.490411 \\
\hline$\infty$ & 0.287872 & 0.205378 & 0.693721 & 0.458474 & 0.283889 & 0.515179 \\
\hline steady state & 0.345362 & 0.246671 & 1.524281 & 0.583704 & 0.362003 & 1.236473 \\
\hline
\end{tabular}

calculations and those accounting for the full transition path are small for the labor income and consumption tax, the differences are substantial for the capital income tax. For the U.S., the comparison across steady states gives a welfare loss of $1.5 \%$ of output; accounting for the transition path lowers this cost by over a factor of two to $0.7 \%$. Results for the EMU reveal a similar pattern with the steady state welfare cost being measured at $1.2 \%$ of output while the transition path places the cost at a more modest $0.5 \%$. Looking across the different horizons for the capital income tax increase shows that there are measured welfare gains in the short term that are offset by later welfare losses. These short term welfare gains reflect the fact that along the transition path, consumption is higher than its previous steady state value (reflecting the capital decumulation along the transition path), and hours of work are lower.

\subsection{Deficit-neutral capital tax reductions}

A common result from the optimal fiscal policy literature is that capital income taxes should be lower - typically, zero in the long run - see Judd (1985), Chamley (1986) and Atkeson et al. (1999). In this spirit, this section considers tax reforms involving a reduction in the capital income tax rate targeted to amount to one percent of GDP. Deficits are treated as a constraint on fiscal policy and so this capital income tax reduction must be financed by raising either the labor income or consumption tax. As with the deficit reduction experiments, policymakers do not take into account the general equilibrium effects of their tax rate changes. Instead, 
they figure out how to adjust taxes so that the deficit would remain unchanged if the tax base remained unchanged.

Figure 4 summarizes the results for the U.S. Comparing Figure 2 with Figure 4 shows that the effects of the capital income tax cut dominate the responses in Figure 4. Roughly speaking, the results of replacing the capital income tax with another tax are the horizontal summation of the mirror image of the response to the capital income tax and the response of the other tax from Figure 2. As in Figure 2, qualitatively the responses of replacing the capital income tax with either a labor income tax or consumption tax are quite similar. Output rises as do hours of work. The lower capital income tax encourages capital accumulation, so investment rises; consumption falls to accommodate this rise in investment. The real exchange rate appreciates on impact, then depreciates. After 60 quarters (15 years), the real exchange rate has depreciated relative to its previous steady state value. On impact, the sharp appreciation of the real exchange rate leads to a current account deficit. As above, the reason for this current account deficit is the revaluation of U.S. net foreign assets. The appreciation of the real exchange rate tends to reduce exports and increase imports; net exports fall. One perhaps happy result is that the government deficit as a percent of GDP falls in both cases. In large part, the fall in the deficit-to-GDP ratio can be attributed to the rise in output; only a small part is due to an actual increase in government revenues.

Qualitatively, the results for the EMU, presented in Figure 5, are similar to those of the U.S. One substantive difference is that when the capital income tax revenue is replaced by consumption tax revenue, there is a marked increase in the EMU budget deficit in the short term (up to 10 years) while the U.S exhibits a smaller and shorter lived increase. On impact, since the capital stock is given, revenue from taxing capital income falls. For the EMU, under the consumption tax scenario, hours worked fall, further reducing government tax revenues. Finally, consumption falls and so the increase in the consumption tax is insufficient to offset the tax revenue losses associated with factor incomes. The chief difference between the U.S. and EMU is that for the U.S., hours initially rise under the consumption tax scenario whereas 
Figure 4: Deficit-neutral capital income tax cut in the U.S.

(a) Output

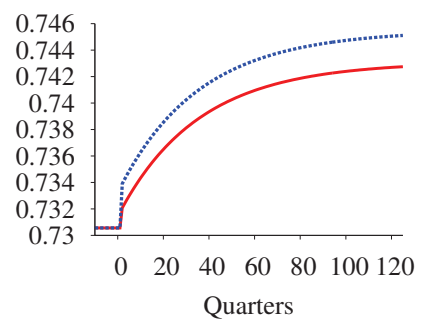

(d) Capital Stock

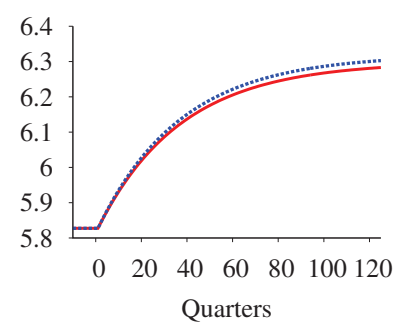

(g) Real Exch. Rate

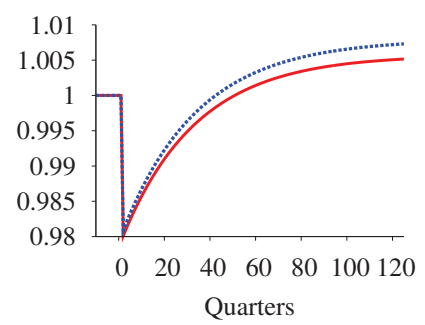

(b) Consumption

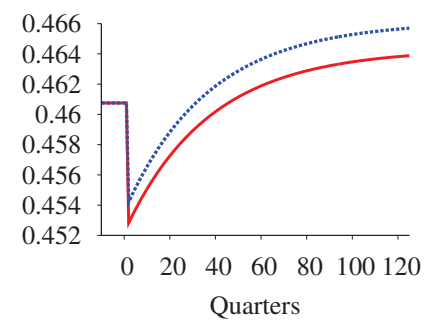

(e) Real Int. Rate

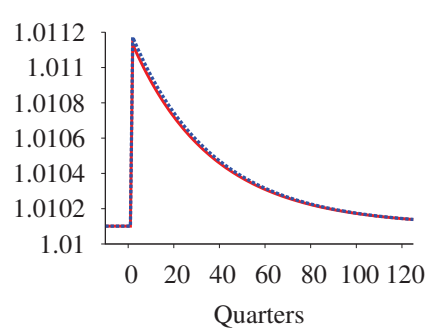

(h) Net Exports

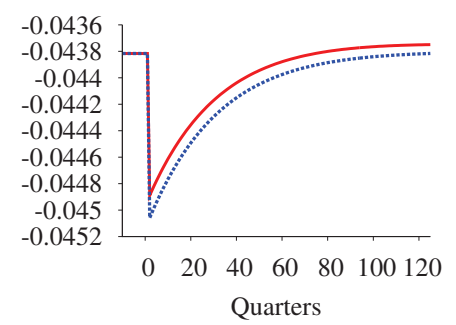

(c) Hours

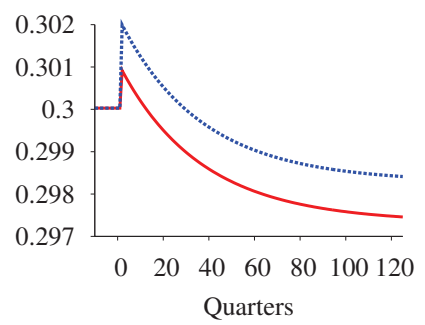

(f) Deficit (\% of GDP)

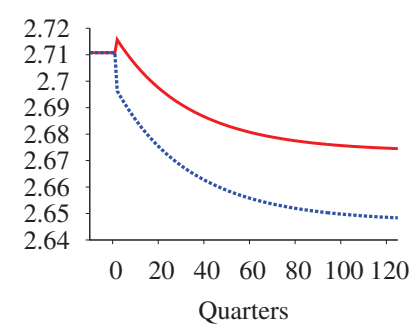

(i) $\mathrm{CA}(\%$ of GDP)

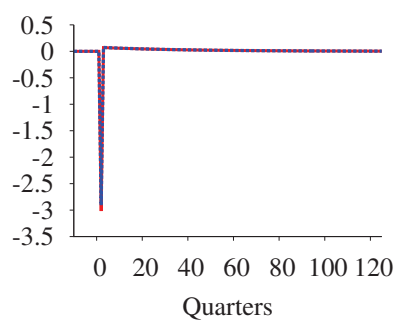

Legend: solid red line, increase in $\tau_{c}$; dotted blue line, increase in $\tau_{h}$. The reduction in the capital income tax rate is 6.2 percentage points. The increase in the labor income tax rate is 1.4 percentage points; that for the consumption tax, 1.6 percentage points. 
Figure 5: Deficit-neutral capital income tax cut in the EMU.

(a) Output

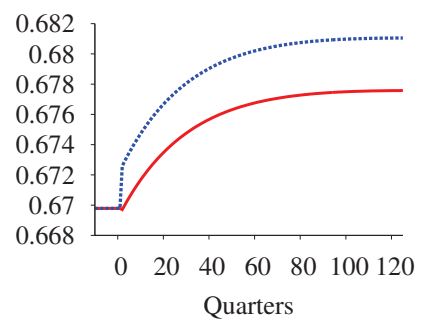

(d) Capital Stock

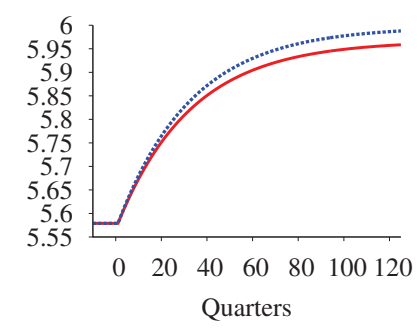

(g) Real Exch. Rate

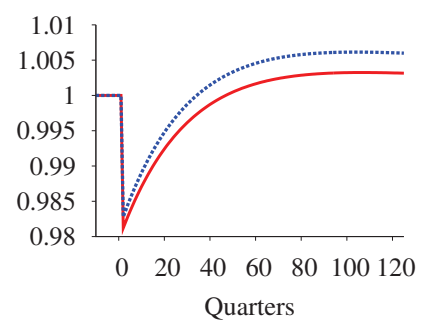

(b) Consumption

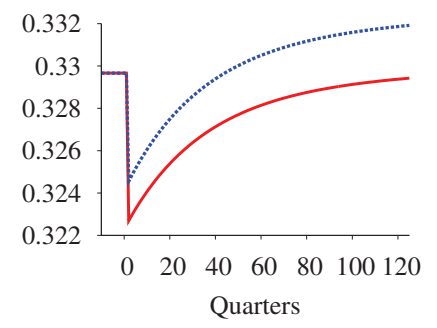

(e) Real Int. Rate

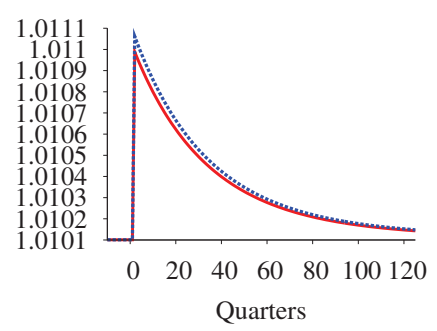

(h) Net Exports

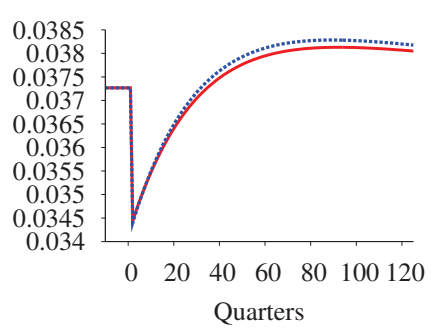

(c) Hours

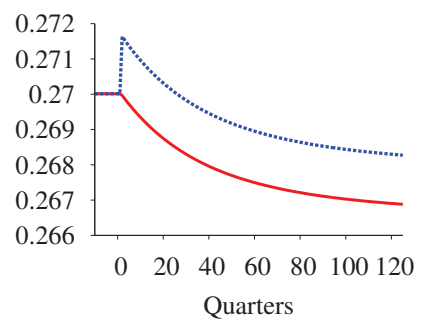

(f) Deficit (\% of GDP)

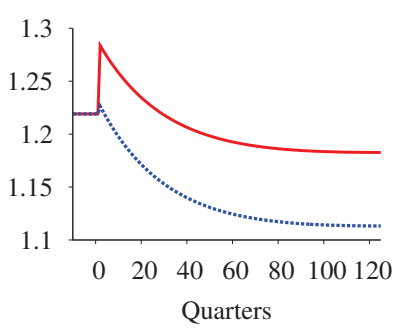

(i) $\mathrm{CA}(\%$ of GDP)

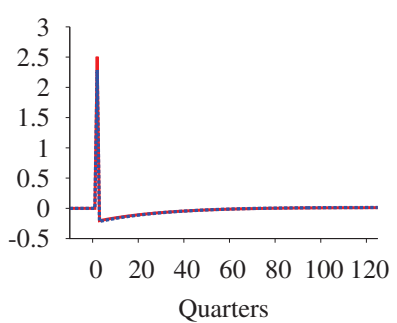

Legend: solid red line, increase in $\tau_{c}$; dotted blue line, increase in $\tau_{h}$. The reduction in the capital income tax rate is 6.2 percentage points. The increase in the labor income tax rate is 1.4 percentage points; that for the consumption tax, 1.6 percentage points. 
Table 4: Deficit-neutral tax changes: Welfare losses as a percentage of steady state output

\begin{tabular}{|c|c|c|c|c|c|c|}
\hline \multirow[b]{2}{*}{ Reduce: } & \multicolumn{3}{|c|}{ U.S. } & \multicolumn{3}{|c|}{ EMU } \\
\hline & $\tau_{k}$ & $\tau_{k}$ & $\tau_{h}$ & $\tau_{k}$ & $\tau_{k}$ & $\tau_{h}$ \\
\hline Increase: & $\tau_{h}$ & $\tau_{c}$ & $\tau_{c}$ & $\tau_{h}$ & $\tau_{c}$ & $\tau_{c}$ \\
\hline Horizon & & & & & & \\
\hline 1 & 1.221118 & 1.197406 & -0.026974 & 1.035293 & 0.950010 & -0.085657 \\
\hline 4 & 1.137529 & 1.110220 & -0.029740 & 0.979572 & 0.889363 & -0.089543 \\
\hline 16 & 0.852931 & 0.813491 & -0.039199 & 0.791126 & 0.684215 & -0.102929 \\
\hline$\infty$ & -0.261607 & -0.344910 & -0.075089 & 0.049993 & -0.126449 & -0.161949 \\
\hline steady state & -0.901506 & -1.003721 & -0.090547 & -0.433475 & -0.661773 & -0.207364 \\
\hline
\end{tabular}

hours fall in the EMU.

Turning now to the welfare gains and losses, Table 4 shows that replacing capital income tax revenue with either labor income or consumption tax revenue generates welfare gains for the U.S. (see the line associated with the infinite horizon), but only the consumption tax leads to welfare gains for the EMU. Comparing welfare gains across steady states is quite misleading in this case. For the U.S., using labor income tax revenue to lower the capital income tax rate gives a welfare gain of $0.9 \%$ of output; accounting for the transition path lowers that gain by a factor of three to $0.3 \%$. The story is similar for the U.S. consumption tax scenario. For the EMU, the labor income tax scenario leads to a welfare gain of $0.4 \%$ when computed across steady states, but a modest welfare loss ( $0.05 \%$ of output) when the transition path is included. In all cases, there are substantial welfare losses in the short term; it is only at long horizons that the welfare gains arise (if at all).

\subsection{Deficit-neutral labor income tax reductions}

There has been a debate among economists and policymakers whether a reduction in labor income taxes, accompanied by an increase in consumption taxes to offset the lost labor income tax revenue, can improve a country's competitiveness, reduce the distortion associated with the labor income tax, while paying for this labor income tax reduction in part by taxing imported goods. This last effect occurs because, in an open economy, the consumption tax 
applies to both domestic and imported goods, so part of the burden of the higher consumption tax will be borne by foreign producers. The final experiment addresses this issue by reducing the labor income tax, targeted at one percent of GDP based on the current tax base, with an accompanying increase in the consumption tax, designed to keep the deficit-to-GDP ratio unchanged (again, based on the current tax base).

The U.S. case is summarized in Figure 6; the EMU in Figure 7. Apart from the current account dynamics, the two cases look quite similar. There is a modest boost to output, consumption and hours; the capital stock declines slightly. Although the tax changes were intended to leave the deficit-to-GDP ratio unchanged, in fact there is a moderate fall. The real exchange rate experiences a small depreciation. On impact, net exports fall, but then rise above their previous steady state value.

For the welfare implications, once again consult Table 4. In this case, there are uniformly welfare gains, although they are fairly modest. In terms of lifetime utility (consult the infinite horizon case) and accounting for the transition path, there is a welfare gain of less than $0.1 \%$ for the U.S. of switching some labor income tax revenue to the consumption tax; the gain is somewhat higher for the EMU, but still less than $0.2 \%$ of output. 
Figure 6: Deficit-neutral labor income tax reduction: U.S.

(a) Output

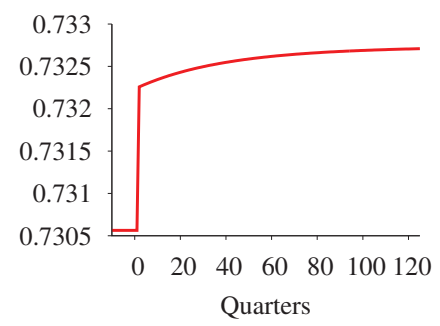

(d) Capital Stock

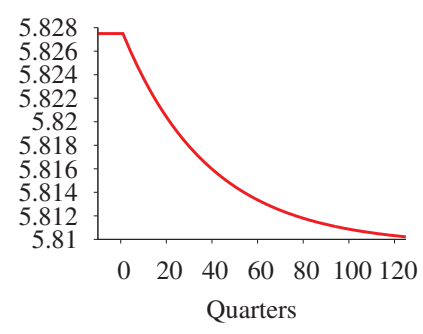

(g) Real Exch. Rate

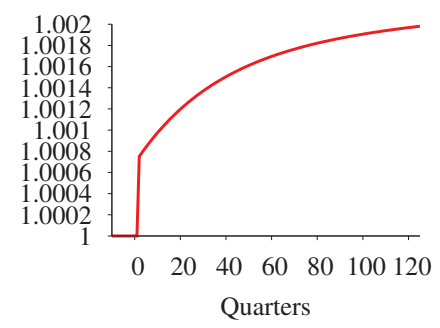

(b) Consumption

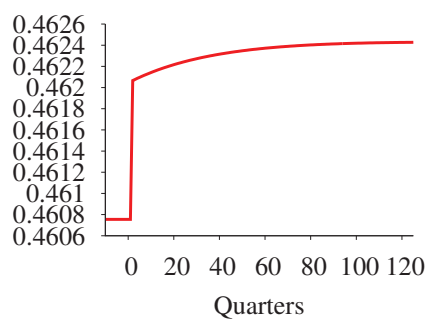

(e) Real Int. Rate

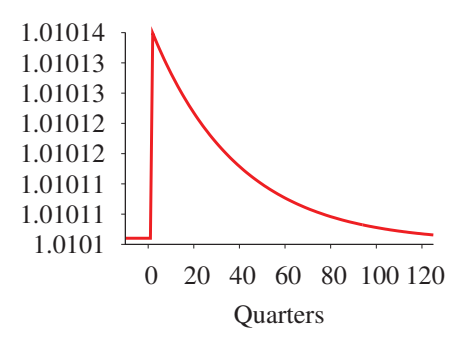

(h) Net Exports

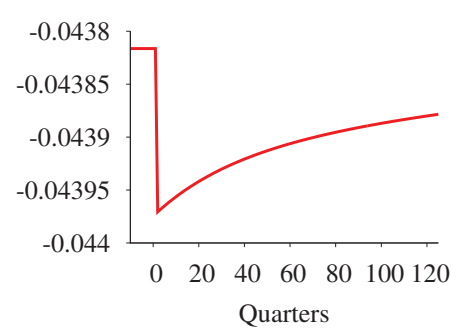

(c) Hours

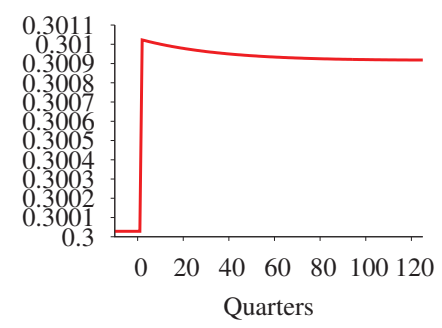

(f) Deficit (\% of GDP)

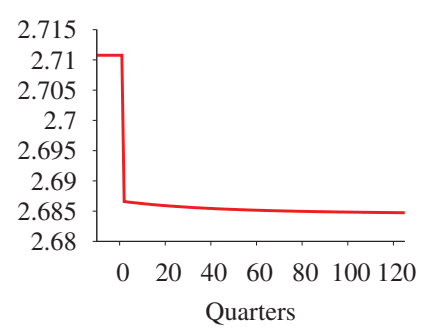

(i) $\mathrm{CA}(\%$ of GDP)

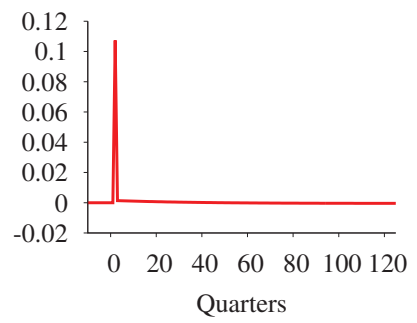

Legend: The reduction in the labor income tax rate is 1.4 percentage points; the increase in the consumption tax, 1.6 percentage points. 
Figure 7: Deficit-neutral labor income tax reduction: EMU.

(a) Output

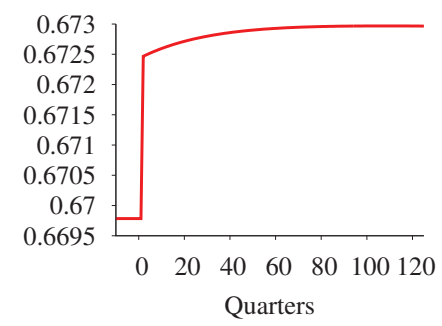

(d) Capital Stock

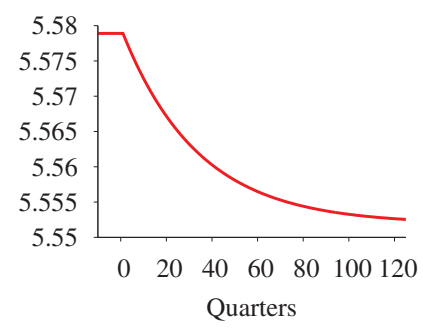

(g) Real Exch. Rate

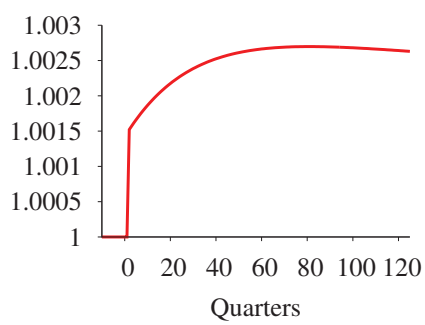

(b) Consumption

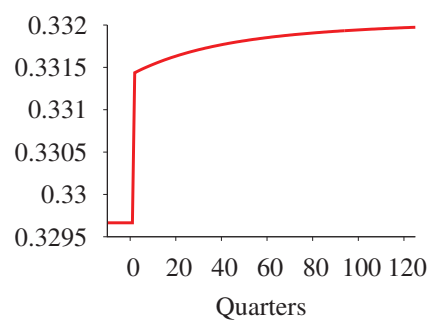

(e) Real Int. Rate

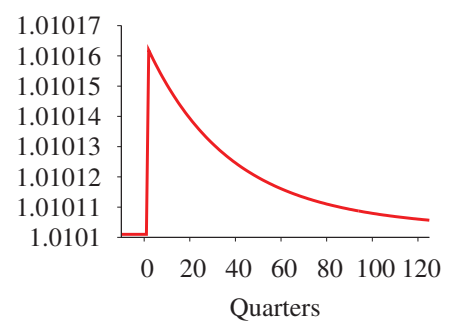

(h) Net Exports

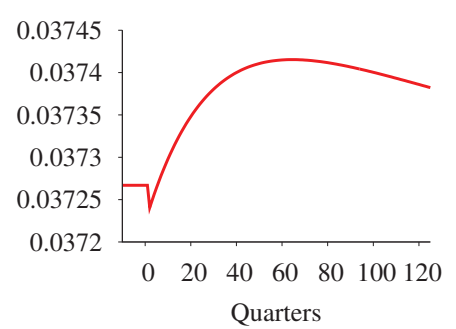

(c) Hours

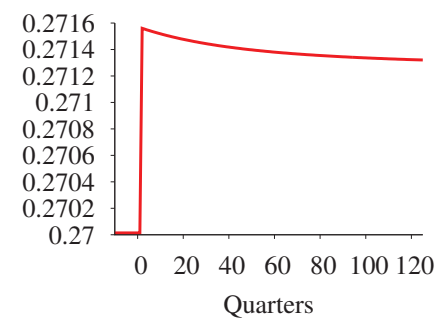

(f) Deficit (\% of GDP)

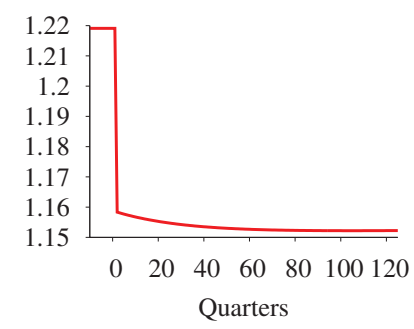

(i) $\mathrm{CA}(\%$ of GDP)

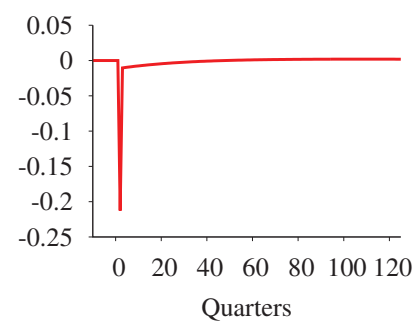

Legend: The reduction in the labor income tax rate is 1.4 percentage points; the increase in the consumption tax, 2 percentage points. 


\section{Conclusion}

This paper constructed an open economy macroeconomic model. Key features included a full set of tax instruments (capital income, labor income, consumption) and incomplete financial markets (allowing for wealth transfers following a policy change). The model was calibrated to two economies, the first being the U.S., the other a subset of the EMU.

Broadly speaking, two sets of policy experiments were conducted. The first consisted of permanent tax increases geared to reducing the government deficit-to-GDP ratio by one percentage point. This first set of experiments was motivated by recent events pointing to the need for fiscal reform in a number of developed countries. In changing taxes, the government took the existing tax base as given and so did not account for general equilibrium effects. Welfare losses were computed accounting for the transition path. Since the model was of an open economy, the consumption tax applied to both domestic and imported goods, breaking the closed economy equivalence between the consumption and labor income taxes. Consequently, of the three tax increases, the consumption tax was the least costly in terms of welfare. It was also the most successful tax increase in terms of deficit reduction, although none of the tax increases came very close to reducing the deficit-to-GDP ratio by one percentage point. Both the consumption and labor income tax increases depressed macroeconomic activity, a modest appreciated the real exchange rate, and increased net exports. On impact, the U.S. experienced a decline in the current account while the EMU showed an increase. The difference can be attributed to the difference in net foreign assets; the U.S. is a net creditor while the EMU is a net debtor. The current account balance movement is dominated by a revaluation effect on net foreign assets associated with real exchange rate variations. The increase in the capital income tax lead to a short term increase in consumption as households drew down their capital stocks. Over short horizons, the increased capital income tax lead to measured welfare gains although in terms of lifetime utility, there was a substantial welfare loss.

The second set of experiments were tax changes designed to be deficit-neutral. Reductions 
in the capital income tax rate, financed by either an increased consumption or labor income tax, were motivated by optimal taxation considerations. Under both scenarios, long run welfare gains were computed, although at short horizons there were welfare losses. The macroeconomic effects were largely the mirror image of the permanent capital income tax increases considered earlier. Reductions in the labor income tax, financed by an increase in the consumption tax, were motivated by suggestions that such a change in the mix of taxes would increase international competitiveness, reduce the inefficiencies associated with labor income taxation, and that the labor income tax reduction could be financed in part by taxing imported goods. The simulations found support for these positions. The real exchange rate depreciated, improving competitiveness; there was a modest boom in macroeconomic activity; and there were modest welfare gains. 


\section{A Summary of equilibrium conditions in real terms}

Labor supply:

$$
\begin{gathered}
-\frac{u_{h, t}}{u_{c, t}}-\frac{\left(1-\tau_{h, t}\right)}{\left(1+\tau_{c, t}\right)} w_{t}\left(\varphi+(1-\varphi) s_{t}^{1-\mu}\right)^{\frac{1}{\mu-1}}=0, \\
-\frac{u_{h, t}^{*}}{u_{c, t}^{*}}-\frac{\left(1-\tau_{h, t}^{*}\right)}{\left(1+\tau_{c, t}^{*}\right)} w_{t}^{*}\left(\left(1-\varphi^{*}\right)^{1-\mu}+\varphi^{*} s_{t}^{\mu-1}\right)^{\frac{1}{\mu-1}}=0 .
\end{gathered}
$$

Accumulation of domestic bonds:

$$
\begin{aligned}
\frac{u_{c, t}}{\left(1+\tau_{c, t}\right)} & =\beta E_{t}\left\{\frac{r_{t+1} u_{c, t+1}}{\left(1+\tau_{c, t+1}\right)}\right\}, \\
\frac{u_{c, t}^{*}}{\left(1+\tau_{c, t}^{*}\right)} & =\beta E_{t}\left\{\frac{r_{t+1}^{*} u_{c, t+1}^{*}}{\left(1+\tau_{c, t+1}^{*}\right)}\right\} .
\end{aligned}
$$

Accumulation of physical capital:

$$
\begin{gathered}
\frac{q_{t} u_{c, t}}{\left(1+\tau_{c, t}\right)}=\beta E_{t}\left\{\frac{u_{c, t+1}}{\pi_{c, t+1}\left(1+\tau_{c, t}\right)}\left(q_{t+1}+\left(1-\tau_{k, t+1}\right)\left(z_{t+1}-\delta\right)\right)\right\}, \\
\frac{q_{t}^{*} u_{c, t}^{*}}{\left(1+\tau_{c, t}^{*}\right)}=\beta E_{t}\left\{\frac{u_{c, t+1}^{*}}{\pi_{c, t+1}^{*}\left(1+\tau_{c, t}^{*}\right)}\left(q_{t+1}^{*}+\left(1-\tau_{k, t+1}^{*}\right)\left(z_{t+1}^{*}-\delta\right)\right)\right\},
\end{gathered}
$$

Tobin's $Q$ definition:

$$
\begin{gathered}
q_{t}=1+\phi_{k}\left(k_{t}-k_{t-1}\right), \\
q_{t}^{*}=1+\phi_{k}\left(k_{t}^{*}-k_{t-1}^{*}\right) .
\end{gathered}
$$

Modified interest rate parity:

$$
\left[1+\phi_{f}\left(f_{t}^{r}-f^{r}\right)\right] \frac{s_{t}^{r} u_{c}\left(c_{t}, h_{t}\right)}{1+\tau_{c, t}}=\beta E_{t}\left\{\frac{s_{t+1}^{r} u_{c}\left(c_{t+1}, h_{t+1}\right) r_{t+1}^{*}}{1+\tau_{c, t+1}}\right\}
$$

Production functions:

$$
\begin{gathered}
y_{t}=a_{t} k_{t-1}^{\phi} h_{t}^{1-\phi} \\
y_{t}^{*}=a_{t}^{*} k_{t-1}^{* \phi} h_{t}^{* 1-\phi} .
\end{gathered}
$$


Factors use:

$$
\begin{aligned}
& (1-\phi) z_{t} k_{t-1}=\phi w_{t} h_{t}, \\
& (1-\phi) z_{t}^{*} k_{t-1}^{*}=\phi w_{t}^{*} h_{t}^{*} .
\end{aligned}
$$

Pricing:

$$
\begin{aligned}
w_{t}^{1-\phi} z_{t}^{\phi} & =\phi^{\phi}(1-\phi)^{1-\phi} a_{t}, \\
w_{t}^{* 1-\phi} z_{t}^{* \phi} & =\phi^{\phi}(1-\phi)^{1-\phi} a_{t}^{*} .
\end{aligned}
$$

Public debt:

$$
\begin{gathered}
d_{r, t}-r_{t-1} d_{r, t-1}=g_{t}-\left(\varphi+(1-\varphi) s_{t}^{1-\mu}\right)^{\frac{1}{1-\mu}} \tau_{c, t} c_{t}-\tau_{h, t} w_{t} h_{t}-\tau_{k, t}\left(z_{t}-\delta\right) k_{t-1}, \\
d_{r, t}^{*}-r_{t-1}^{*} d_{r, t-1}^{*}=g_{t}^{*}-\left(1-\varphi^{*}+\varphi^{*}\left(s_{t}\right)^{\mu-1}\right)^{\frac{1}{1-\mu}} \tau_{c, t}^{*} c_{t}^{*}-\tau_{h, t}^{*} w_{t}^{*} h_{t}^{*}-\tau_{k, t}^{*}\left(z_{t}^{*}-\delta\right) k_{t-1}^{*},
\end{gathered}
$$

where $d_{r, t}=d_{t} / p_{t}$ and $d_{r, t}^{*}=d_{t}^{*} / p_{t}^{*}$.

Final goods market clearing:

$$
\begin{aligned}
y_{t} & =\varphi\left(\varphi+(1-\varphi) s_{t}^{1-\mu}\right)^{\frac{\mu}{1-\mu}}\left(c_{t}+a c_{f, t}\right)+(1-\varphi)\left(\left(1-\varphi^{*}\right) s_{t}^{1-\mu}+\varphi^{*}\right)^{\frac{\mu}{1-\mu}} c_{t}^{*} \\
& +k_{t}-(1-\delta) k_{t-1}+g_{t}+a c_{k, t}, \\
y_{t}^{*} & =\left(1-\varphi^{*}\right)\left(\left(1-\varphi^{*}\right)+\varphi^{*} s_{t}^{\mu-1}\right)^{\frac{\mu}{1-\mu}} c_{t}^{*}+\varphi^{*}\left(\varphi s_{t}^{\mu-1}+(1-\varphi)\right)^{\frac{\mu}{1-\mu}}\left(c_{t}+a c_{f, t}\right) \\
& +k_{t}^{*}-(1-\delta) k_{t-1}^{*}+g_{t}^{*}+a c_{k, t}^{*} .
\end{aligned}
$$

Net foreign assets:

$$
f_{t}^{r}-r_{t-1}^{*} \frac{s_{t}^{r}}{s_{t-1}^{r}} f_{t-1}^{r}=(1-\varphi) \Upsilon_{2}\left(s_{t}\right) c_{t}^{*}-\left(1-\varphi \Upsilon_{1}\left(s_{t}\right)\right)\left(c_{t}+a c_{f, t}\right),
$$


where:

$$
\begin{gathered}
\Upsilon_{1}\left(s_{t}\right)=\left(\varphi+(1-\varphi) s_{t}^{1-\mu}\right)^{-1}, \\
\Upsilon_{2}\left(s_{t}\right)=\left(\Upsilon_{1}\left(s_{t}\right)\left(\left(1-\varphi^{*}\right) s_{t}^{1-\mu}+\varphi^{*}\right)^{\mu}\right)^{\frac{1}{1-\mu}} .
\end{gathered}
$$

Relation between real exchange rate and terms of trade:

$$
s_{t}^{r}=\left(\frac{\left(1-\varphi^{*}\right) s_{t}^{1-\mu}+\varphi^{*}}{\varphi+(1-\varphi) s_{t}^{1-\mu}}\right)^{\frac{1}{1-\mu}} .
$$

CPI inflation rates:

$$
\begin{gathered}
\pi_{c, t}=\left(\frac{\varphi+(1-\varphi) s_{t}^{1-\mu}}{\varphi+(1-\varphi) s_{t-1}^{1-\mu}}\right)^{\frac{1}{1-\mu}}, \\
\pi_{c, t}^{*}=\left(\frac{\left(1-\varphi^{*}\right)+\varphi^{*} s_{t}^{\mu-1}}{\left(1-\varphi^{*}\right)+\varphi^{*}} s_{t-1}^{\mu-1}\right)^{\frac{1}{1-\mu}} .
\end{gathered}
$$

\section{B Steady state}

The steady state of this economy obtains as follows. Since we abstract from growth in the steady state, Euler equations and the definition of Tobin's Q yields:

$$
r=r^{*}=\beta^{-1}, \text { and } q=q^{*}=1 .
$$

The dynamics of Tobin's Q thus implies:

$$
z=\frac{\beta^{-1}-1}{1-\tau_{k}}+\delta, \text { and } z^{*}=\frac{\beta^{-1}-1}{1-\tau_{k}^{*}}+\delta .
$$

Once $z$ and $z^{*}$ are known, real wages are known:

$$
w=(1-\phi)\left(\frac{\phi}{z}\right)^{\frac{\phi}{1-\phi}} a^{\frac{1}{1-\phi}}, \text { and } w^{*}=(1-\phi)\left(\frac{\phi}{z^{*}}\right)^{\frac{\phi}{1-\phi}} a^{*} \frac{1}{1-\phi} .
$$

Then, using the relation between input prices, we can express capital as a function of 
hours:

$$
k=\left(\frac{\phi a}{z}\right)^{\frac{1}{1-\phi}} h, \text { and } k^{*}=\left(\frac{\phi a^{*}}{z^{*}}\right)^{\frac{1}{1-\phi}} h^{*} .
$$

Hence, the production function writes:

$$
y=a^{\frac{1}{1-\phi}}\left(\frac{\phi}{z}\right)^{\frac{\phi}{1-\phi}} h, \text { and } y^{*}=a^{* \frac{1}{1-\phi}}\left(\frac{\phi}{z^{*}}\right)^{\frac{\phi}{1-\phi}} h^{*} .
$$

Then the labor supply equations:

$$
\begin{gathered}
-\frac{u_{h}}{u_{c}}-\frac{\left(1-\tau_{h}\right)}{\left(1+\tau_{c}\right)}(1-\phi) \frac{\phi^{\frac{\phi}{1-\phi}}}{z} a^{\frac{1}{1-\phi}}\left(\varphi+(1-\varphi) s^{1-\mu}\right)^{\frac{1}{\mu-1}}=0, \\
-\frac{u_{h}^{*}}{u_{c}^{*}}-\frac{\left(1-\tau_{h}^{*}\right)}{\left(1+\tau_{c}^{*}\right)}(1-\phi)\left(\frac{\phi}{z^{*}}\right)^{\frac{\phi}{1-\phi}} a^{* \frac{1}{1-\phi}}\left(\left(1-\varphi^{*}\right)^{1-\mu}+\varphi^{*} s^{\mu-1}\right)^{\frac{1}{\mu-1}}=0,
\end{gathered}
$$

and final goods market clearing conditions:

$$
\begin{aligned}
& a^{\frac{1}{1-\phi}}\left(\frac{\phi}{z}\right)^{\frac{\phi}{1-\phi}} h=\varphi\left(\varphi+(1-\varphi) s^{1-\mu}\right)^{\frac{\mu}{1-\mu}} c \\
& +\frac{\varphi^{*}(1-n)}{n}\left(\left(1-\varphi^{*}\right) s^{1-\mu}+\varphi^{*}\right)^{\frac{\mu}{1-\mu}} c^{*}+\delta\left(\frac{\phi a}{z}\right)^{\frac{1}{1-\phi}} h+g, \\
& a^{* \frac{1}{1-\phi}}\left(\frac{\phi}{z^{*}}\right)^{\frac{\phi}{1-\phi}} h^{*}=\left(1-\varphi^{*}\right)\left(\left(1-\varphi^{*}\right)+\varphi^{*} s^{\mu-1}\right)^{\frac{\mu}{1-\mu}} c^{*} \\
& +\frac{(1-\varphi) n}{1-n}\left(\varphi s^{\mu-1}+(1-\varphi)\right)^{\frac{\mu}{1-\mu}} c+\delta\left(\frac{\phi a^{*}}{z^{*}}\right)^{\frac{1}{1-\phi}} h^{*}+g^{*},
\end{aligned}
$$

form a 4 equations static system with 5 unknowns $\left(c, c^{*}, h, h^{*}, s\right)$. With incomplete assets markets, the model can be closed with the equation of net foreign assets:

$$
f^{r}=\frac{(1-\varphi) \Upsilon_{2}(s) c^{*}-\left(1-\varphi \Upsilon_{1}(s)\right) c}{1-\beta^{-1}}
$$

Because we are still left with one undetermined variable in the steady state, we choose to normalize $s=1$ in the steady state. Given these assumptions, and the form of the utility function, steady state relations thus give:

$$
h^{*}=\frac{(\theta+\varphi \psi)\left(\left(1-\varphi^{*}\right) \psi^{*}+\varphi^{*} \psi\right)-\varphi^{*} \psi\left(\varphi \psi+(1-\varphi) \psi^{*}\right)}{(\theta+\varphi \psi)\left(\theta^{*}+\left(1-\varphi^{*}\right) \psi^{*}\right)-\varphi^{*} \psi(1-\varphi) \psi^{*}},
$$




$$
h=\frac{\varphi \psi}{\theta+\varphi \psi}-\frac{(1-\varphi) \psi^{*}}{\theta+\varphi \psi}\left(1-h^{*}\right), c^{*}=\psi^{*}\left(1-h^{*}\right), c=\psi(1-h),
$$

where:

$$
\begin{gathered}
\psi=\frac{\kappa}{1-\kappa} \frac{\left(1-\tau_{h}\right)}{\left(1+\tau_{c}\right)}(1-\phi) \frac{\phi}{z}^{\frac{\phi}{1-\phi}} a^{\frac{1}{1-\phi}}, \quad \psi^{*}=\frac{\kappa}{1-\kappa} \frac{\left(1-\tau_{h}^{*}\right)}{\left(1+\tau_{c}^{*}\right)}(1-\phi)\left(\frac{\phi}{z^{*}}\right)^{\frac{\phi}{1-\phi}} a^{* \frac{1}{1-\phi}}, \quad(74) \\
\theta=a^{\frac{1}{1-\phi}}\left(\frac{\phi}{z}\right)^{\frac{\phi}{1-\phi}}\left(1-\gamma_{g}\right)-\delta\left(\frac{\phi a}{z}\right)^{\frac{1}{1-\phi}}, \quad \theta^{*}=a^{* \frac{1}{1-\phi}}\left(\frac{\phi}{z^{*}}\right)^{\frac{\phi}{1-\phi}}\left(1-\gamma_{g}^{*}\right)-\delta\left(\frac{\phi a^{*}}{z^{*}}\right)^{\frac{1}{1-\phi}},
\end{gathered}
$$

and $\gamma_{g}=g / y$ and $\gamma_{g}^{*}=g^{*} / y^{*}$. Consequently, steady state net foreign assets are:

$$
f^{r}=\frac{(1-\varphi)\left(c^{*}-c\right)}{1-\beta^{-1}}
$$

and steady state public debts:

$$
\begin{gathered}
\left(1-\beta^{-1}\right) d_{r}=g-\tau_{c} c-\tau_{h} w h-\tau_{k}(z-\delta) k, \\
\left(1-\beta^{-1}\right) d_{r}^{*}=g^{*}-\tau_{c}^{*} c^{*}-\tau_{h}^{*} w^{*} h^{*}-\tau_{k}^{*}\left(z^{*}-\delta\right) k^{*} .
\end{gathered}
$$

\section{Data for calibration}

We use data from various OECD databases to calibrate our models. We consider the following OECD countries: Australia, Austria, Belgium, Canada, Czech, Republic, Denmark, Finland, France, Germany, Greece, Hungary, Ireland, Italy, Japan, Korea, Luxembourg, Mexico, Netherlands, New Zealand, Norway, Poland, Portugal, Slovak Republic, Spain, Sweden, Switzerland, United Kingdom, and United States. The following elements are used:

- Total labor wedge on labor income for average wage in 2008 (extracted from the OECD tax database).

- VAT rate in 2008 (extracted from the OECD tax database). 
- Corporate and personal income tax rate on dividends in 2008 (extracted from the OECD tax database).

- Total GDP in 2008, in millions of US\$, in 2000 constant prices and constant PPP.

- Total imports in 2008, in millions of US\$, in 2000 constant prices and constant PPP.

- Total population in 2008 , in thousands of persons.

- Total employment (domestic concept) in 2008, in thousands of persons.

- Average annual hours actually worked in 2008.

- Government expenditure in 2008, as a \% of annual GDP (extracted from national annual accounts).

- Social transfers in 2008, as a \% of annual GDP (extracted from national annual accounts). 


\section{References}

Atkeson, Andrew, Patrick J. Kehoe, and V. V. Chari, "Taxing Capital Income: A Bad Idea," Federal Reserve Bank of Minneapolis Quarterly Review, Summer 1999, 23, 3-17.

Auray, Stephane, Beatriz de Blas, and Aurélien Eyquem, "Ramsey Policies in a Small Open Economy with Sticky Prices and Capital," Journal of Economic Dynamics and Control, 2011. forthcoming.

Backus, David K, Patrick J Kehoe, and Finn E Kydland, "International Real Business Cycles," Journal of Political Economy, 1992, 100 (4), 745-775.

Backus, David K., Patrick J. Kehoe, and Finn E. Kydland, "International Business Cycles: Theory vs. Evidence," Federal Reserve Bank of Minneapolis Quarterly Review, 1993, Fall, 14-29.

Benigno, Gianluca and Bicanca de Paoli, "On the International Dimension of Fiscal Policy," Journal of Money, Credit and Banking, December 2010, 42 (8), 1523-1542.

Benigno, Pierpaolo, "Price Stability with Imperfect Financial Integration," Journal of Money, Credit and Banking, 2009, 41 (s1), 121-149.

Chamley, Christophe, "Optimal Taxation of Capital Income in General Equilibrium with Infinite Lives," Econometrica, May 1986, 54 (3), 607-622.

Chari, V. V. and Patrick J. Kehoe, "Optimal fiscal and monetary policy," in J. B. Taylor and M. Woodford, eds., Handbook of Macroeconomics, Vol. 1 of Handbook of Macroeconomics, Elsevier, June 1999, chapter 26, pp. 1671-1745.

Gomme, Paul and Peter Rupert, "Theory, Measurement, and Calibration of Macroeconomic Models," Journal of Monetary Economics, March 2007, 54 (2), 460-497. 
Judd, Kenneth L., "Redistributive Taxation in a Simple Perfect Foresight Model," Journal of Public Economics, October 1985, 28, 59-83.

Lucas, Jr., Robert E., "Econometric Policy Evaluation: A Critique," Carnegie-Rochester Conference Series on Public Policy, 1976, 1, 19-46.

Lucas, R. and N. Stokey, "Optimal Fiscal and Monetary Policy in an Economy without Capital," Journal of Monetary Economics, 1983, 12 (1), 55-93.

Mendoza, E. G., "Real Business Cycles in a Small Open Economy," American Economic Review, 1991, 81 (4), 797-818.

Mendoza, Enrique G., "Real Business Cycles in a Small Open Economy," American Economic Review, September 1991, 81 (4), 797-818.

Schmitt-Grohé, Stephanie and Martin Uribe, "Closing Small Open Economy Models," Journal of International Economics, 2003, 61 (1), 163-185. 